\title{
Bioethanol production with different dosages of the commercial Acrylamide polymer compared to a Bioextract in clarifying sugarcane juice
}

\author{
CRISTHYANE M. FREITA, LIDYANE A. FREITA, LETICIA F. TRALLI, ALINE F. SILVA, \\ FRANCIELE Q. MENDES, VITOR TEIXEIRA and MARCIA J.R. MUTTON
}

\author{
Programa de Pós-Graduação em Microbiologia Agropecuária, Faculdade de Ciências Agrárias e \\ Veterinárias, Departamento de Tecnologia, Universidade Estadual Paulista/UNESP, Via de Acesso \\ Prof. Paulo Donato Castelane, s/n, Vila Industrial, 14884-900 Jaboticabal, SP, Brazil
}

Manuscript received on June 29, 2017; accepted for publication on October 3, 2017

\begin{abstract}
One of the most important steps is to clarify the juice, which are added synthetic polymer acrylamide base, aiming the fast settling of impurities present in the juice. However, this input is expensive and may have carcinogenic and neurotoxic actions to humans. The search for new natural flocculants that have similarity with the commercial product is of great value. A bioextract that may be promising and has coagulant action is the Moringa oleifera Lam. In this context, the objective of the research was to evaluate the consequences of the use of moringa seed extracts and various concentrations of commercial polymer, such as sedimentation aids in clarifying sugarcane juice in the ethanol production, comparing the efficiency of the bioextract moringa. In the treatment of the juice, excessive addition of flocculants can result in reduction of sugars. The bioflocculant moringa was similar in technological features and the fermentative viability compared to usual dose of commercial polymer in Brazil. The fermentation efficiency was also higher for this flocculant, followed by moringa extract. The results obtained in this research indicate potential to the moringa bioextract, particularly in countries where the doses of flocculants are higher than $5 \mathrm{mg} . \mathrm{L}^{-1}$.
\end{abstract}

Key words: Biofuels, Biopolymers, Juice treatment, Moringa oleifera Lam.

\section{INTRODUCTION}

The production of sugarcane in Brazil is growing, the projection of the harvest 2016/2017 indicates a grinding about 630 million tons, an increase of 18.66 million over the total processed in the current season $(2015 / 2016)$, which totaled 617 million tons (UNICA 2016).

This increase mainly results from grinding the expected greater ethanol productivity, whose

Correspondence to: Cristhyane Millena de Freita

E-mail: cristhyanemille@hotmail.com importance has increased in recent years, as a renewable fuel less polluting than oil products and relatively low cost (UNICA 2016).

These attributes were taken into consideration when Brazil, signed the agreement of the $21^{\text {th }}$ Conference of Parties to the United Nations Convention on Climate Change, which set a goal of 10 billion gallons of ethanol by 2025, thus reducing $37 \%$ of greenhouse's gases. However, to achieve this mark will be necessary to advance in cane crushing, find complementary biomass and ensure 
the improvement of the production process of the first generation ethanol (ABBI 2016).

With such a growth forecast, an essential step and costly for the industry is the treatment of the juice, in order to remove inhibiting compounds of the yeast to produce ethanol. Today this process is carried out with addition of synthetic polyelectrolytes (polymers) which has in its acrylamides constitution, this compound may exhibit neurotoxic and carcinogenic actions to human. Studies report that there is no tolerable intake, but this should be as low as possible, with an average intake of $1 \mathrm{mg} \cdot \mathrm{kg}^{-1}(0.001 \mathrm{ppm})$ portion per day, to $4 \mathrm{mg} \cdot \mathrm{kg}^{-1}(0.004 \mathrm{ppm})$ portion per day JECFA, FAO, OMS 2011). Since the yeast in the fermentation process is often recycled and its surplus is used for manufacturing some food and even animal feed (Girotto et al. 2015, Mendes 2016). However, it is important to point that studies or reports that identify this compound in the yeast or mud from the settling process are not found in the literature.

However, this is not the only crucial point, as already mentioned the cost of this product is US $\$ 6.00 / \mathrm{L}$, for which it uses $1.5 \mathrm{ml} . \mathrm{L}^{-1}$, totaling approximately US\$ 9,000.00 a ton. This dosage is used in Brazil, but in Canada this value can reach 20 ml. $\mathrm{L}^{-1}$. Rein 2012, quote that more than $5 \mathrm{mg} . \mathrm{L}^{-1}$ of polymer could be agent of dispersant and it would not be useful for coagulation.

From this perspective, seeking to obtain results through quality gains, natural products are presented as an important alternative that will enable the production process.

Among natural products, extracted plants are highlighted, such as Moringa oleifera Lam. seed, which is widely used as flocculants in water treatment for human consumption (Egbuikwem and Sangodoyin 2013).

In addition, the Moringa oleifera can be produced on site that will be used since it is an easily adaptable plant and fast growing in the first year, the plant can now reach 4 meters high, with flowers and fruits becoming a safe and inexpensive alternative (Awad et al. 2013).

The composition of your protein is a $2 \mathrm{~S}$ albumin, which is the storage of seeds, the main sources of carbon and nitrogen and are involved in plant defense. These properties make moringa seeds with flocculant potential and widely used in water treatment. It is also interesting to note the possible development of antifungal drugs and transgenic crops. Recent studies have shown that Moringa seed is composed of two alpha-helical chains stabilized by four disulfide bridges, which makes it stable and resistant to $\mathrm{pH}$ changes and temperature to $98^{\circ} \mathrm{C}$ (Ullah et al. 2015).

This temperature is extremely important for the treatment of sugarcane juice, since this is heated to $105{ }^{\circ} \mathrm{C}$, and then added flocculants, demonstrating the potential of moringa seeds.

This requires studies to prove the similarity of moringa extract with commercial polymer, aiming the treatment of sugar cane juice, with lower costs and without the presence of acrylamide molecules.

\section{MATERIALS AND METHODS}

INSTALLATION AND CONDUCTION OF THE EXPERIMENT

The experiment was conducted at the Laboratory of Sugar and Alcohol Technology and Fermentation Microbiology - FCAV/UNESP, Jaboticabal-SP campus, in the 2015/2016 harvest. Colms from the CTC5 sugarcane variety were used.

The stems were harvested in the month of June, in their useful period of industrialization, with approximately 14 months of cultivation, due to the fact that the variety used was precocious and and without previous burns of the straw. Moringa seeds and leaves were obtained from an adult plant cultivated in the Horto Florestal at FCAV / UNESP.

The commercial synthetic flocculant used was Kemtalo Sep A3XL (Powdered Anionic Polymers), 
widely used in the power plant of Brazilian midwest.

The broth remained in the laboratory decanter for 20 minutes.

The dosages of the flocculant were:

- $1.5 \mathrm{mg} . \mathrm{L}^{-1}$ of the commercial synthetic flocculant, Kemtalo Sep A3XL;

- $5 \mathrm{mg} . \mathrm{L}^{-1}$ of commercial synthetic flocculant, Kemtalo Sep A3XL;

- $10 \mathrm{mg} \cdot \mathrm{L}^{-1}$ of commercial synthetic flocculant, Kemtalo Sep A3XL;

- $20 \mathrm{mg} . \mathrm{L}^{-1}$ of commercial synthetic flocculant, Kemtalo Sep A3XL;

- 13 mg. $\mathrm{L}^{-1}$ of seed extract Moringa oleifera Lam (Costa et al. 2016).

\section{PREPARATION OF BIOEXTRACT COAGULANT OF} Moringa oleifera LAMARCK

The moringa seeds were collected between May and July 2016. Then, the seeds were placed in a greenhouse at $55{ }^{\circ} \mathrm{C}$ for 12 hours, peeled and macerated manually in a porcelain dish.

For the extraction of the active principle of the seed, 1 gram of seed was added to 100 gram of 1 mol. $\mathrm{L}^{-1} \mathrm{CaCl}$ solution and water. The mixture was stirred for 10 minutes followed by vacuum filtration using qualitative filter paper for the retention of coarse insoluble particles (Okuda et al 2001).

\section{OBTAINING CLARIFIED JUICE}

The juice was obtained by milling. The Brix was adjusted to $16^{\circ}$ and then subjected to a simple calcination process with $\mathrm{pH}$ up to 6.0 and then heating to boiling, adding the flocculation auxiliaries in the decanter prior to the addition of the heated juice.

\section{CHARACTERIZATION OF CLARIFIED JUICE}

The clarified calculations were submitted to analyzes of Brix, Pol, Purity, pH, Total Acidity,
Turbidity, Total Ash (CTC 2011) and Total Phenolic Compounds (Folin and Ciocalteu 1927).

\section{PREPARATION AND CHARACTERIZATION OF MUST}

The clarified juice and molasses were standardized at Brix $16^{\circ}$ and $\mathrm{pH} 4.5$ by the addition of $10 \mathrm{~N}$ sulfuric acid. Then, the Total Acidity and Total Reducing Sugars (TRS) (CTC 2011) were quantified.

\section{FERMENTATION PROCESS}

The must was standardized at $28-32{ }^{\circ} \mathrm{C}$ and inoculated with Saccharomyces cerevisiae yeast at the concentration of $10^{8}$ colony forming units. It should be noted that yeast presented cell viability greater than $85 \%$.

They were fermented in $500 \mathrm{~mL}$ erlenmeyers, which were placed in a B.O.D. with controlled temperature of $30{ }^{\circ} \mathrm{C}$, where it remained until decreasing of the Brix to values below 1, or stabilization in half-hour period.

The must feeding was carried out in two stages, firstly $100 \mathrm{~mL}$ of must was added with the previously adapted yeast, and after 1 hour the volume was supplemented with a further $150 \mathrm{~mL}$.

After 40 minutes of this second feed and at the end of the fermentation process, aliquots were determined to determine cell viability, budding index and viability sprouts (Lee et al. 1981).

At the end of the process, the fermented material was centrifuged at $2500 \mathrm{~g} / 30{ }^{\circ} \mathrm{C}$ for separation of yeast and wine.

\section{CHARACTERIZATION OF WINE}

The wine was submitted to Brix, Total Residual Reduction Sugars (TRRS), pH, Total Acidity (CTC 2011), glycerol (CTC 2011) and alcohol content analysis (reading in Digital Densimeter AntoonPaar DMA 500). 


\section{EXPERIMENTAL DESIGN AND DATA ANALYSIS}

To characterize the results obtained, a randomized block design was used, with 4 replicates. The main treatments consisted of clarified juice with 1 commercial flocculant with 4 different concentrations (Commercial Synthetic Polyelectrolyte) and a Bioextract of Moringa Seeds, in addition to Control treatment (in which no flocculant was added).

The results were submitted to analysis of variance by the $\mathrm{F}$ test, and the means obtained were compared according to the Tukey test (5\%), using the program Assistat version 7.7 beta.

\section{RESULTS AND DISCUSSION}

QUALITY OF RAW MATERIAL

Table I presents the average results obtained for the technological characteristics of the juice extracted from the CTC5 sugarcane variety. Table I shows the analyzes performed for Brix, $\mathrm{pH}$, Pol, Purity and TRS (Total Reducing Sugar), indicating that the sugarcane was within the quality parameters established by the industry, being in the order of 5.0 to 5.5 for $\mathrm{H}_{2} \mathrm{SO}_{4}$ for acidity (Ripoli and Ripoli 2009), Pol $\geq 14 \%$ (Amorim 2006), Purity $\geq 85 \%$ (Amorim 2006) and TRS $\geq 15 \%$ (Amorim 2006), except the acidity which was slightly above $\leq 0.80$ g. $\mathrm{L}^{-1} \mathrm{H}_{2} \mathrm{SO}_{4}$, but this is not a parameter that should be analyzed in isolation.

The Soluble Ash content (Table I) was $0.82 \%$ higher than that reported in the literature of 0.2 to 0.7\% (Delgado and Cesar 1977), this high content may be associated with supplementation of the soil with vinasse, since such an analysis may be indicative of the presence of potassium and calcium in the extracted juice. However, this is a problem for sugar and not to ethanol production, because potassium and calcium can be used as nutrient in the fermentative process (Yang et al. 2016).
Another characteristic determined was Turbidity (Table I), this analysis determines exactly the suspended particles contained in the juice. The stem was harvested in an integral way, what means, with the impurities that were present in the soil, and the value obtained was 1089 NTU. The clarification process interferes directly in this technological parameter, because after the juice treatment these particles should be removed as much as possible to avoid interfering in the fermentation process.

As for the Reducing Sugars (RS) presented in Table I, they were within the established $\leq 0.8 \%$ (Amorim 2006). To maintain plant physiology, there must be the inversion of the sucrose molecule in glucose and levulose (Ripoli and Ripoli 2009). The lower these sugars, the higher will be the metabolic activity of the plant and the greater will be the conversion of these sugars.

Phenolic compounds are biomolecules synthesized by plants, mainly through the acetate pathways. They are one of the most widespread classes of secondary metabolites, being known for their great importance in the soil-plant system. In general, they can be related to metabolic stress, but they are interfering in the alcoholic fermentation, the extracted juice presented values of $406.7 \mathrm{mg} . \mathrm{L}^{-1}$. An efficient fermentative process requires values close to $400 \mathrm{mg} . \mathrm{L}^{-1}$, indicating that the phenolic compounds in the juice was close to the expected one (Costa et al. 2014a, Novoa et al. 2006).

\section{CHARACTERIZATION OF CLARIFIED JUICE}

The evaluation of the chemical-technological characteristics (Brix, pH, Pol, Purity, TRS Acidity, Ashes, Turbidity and Phenolic Compounds) of the clarified juice, aimed to know the effect of the treatments on the process of clarification of the juice and the reflexes on the quality of the juice produced, for industrial processing, for ethanol production. These are presented in Tables II and III. 
TABLE I

Average values obtained for Brix, pH, Acidity, Pol, Purity, TRS, Ash, Turbidity, RS and Phenolic Compounds of extracted juice. Jaboticabal-SP. 2015/2016 crop year.

\begin{tabular}{cccccccccc}
\hline Brix & $\mathbf{p H}$ & $\begin{array}{c}\text { Acidity g/L } \\
\mathbf{H}_{2} \mathbf{S O}_{\mathbf{4}}\end{array}$ & Pol (\%) & Purity (\%) & TRS (\%) & Ash (\%) & $\begin{array}{c}\text { Turbidity } \\
(\mathbf{N T U})\end{array}$ & RS (\%) & $\begin{array}{c}\text { Phenolic } \\
\left(\mathbf{m g . L ^ { - 1 }}\right)\end{array}$ \\
\hline 20.2 & 5.1 & 0.89 & 18.20 & 90.09 & 19.32 & 0.82 & 1089 & 0.69 & 406.7 \\
\hline
\end{tabular}

TABLE II

Mean values obtained for Brix, pH, Pol, Purity and TRS of the clarified juice with 5 different sedimentation aids, from CTC5 sugarcane variet. Jaboticabal-SP. 2015/2016 crop year.

\begin{tabular}{cccccc}
\hline Treatments & Brix & pH & Pol(\%) & Purity(\%) & TRS (\%) \\
\hline Flocculant (F) & $468.0^{* *}$ & $6.8^{* *}$ & $0.53 \mathrm{~ns}$ & $2.52 \mathrm{~ns}$ & $52.26^{* *}$ \\
\hline Control & $15.72 \mathrm{e}$ & $5.9 \mathrm{a}$ & $14.13 \mathrm{a}$ & $82.59 \mathrm{a}$ & $13.43 \mathrm{ab}$ \\
Polimer 1.5 & $16.50 \mathrm{~b}$ & $5.9 \mathrm{a}$ & $14.47 \mathrm{a}$ & $85.23 \mathrm{a}$ & $13.85 \mathrm{a}$ \\
Polimer 5.0 & $16.30 \mathrm{c}$ & $5.9 \mathrm{a}$ & $14.57 \mathrm{a}$ & $85.77 \mathrm{a}$ & $12.57 \mathrm{~b}$ \\
Polimer 10 & $16.20 \mathrm{~d}$ & $5.9 \mathrm{a}$ & $14.43 \mathrm{a}$ & $85.62 \mathrm{a}$ & $10.12 \mathrm{c}$ \\
Polimer 20 & $16.20 \mathrm{~d}$ & $5.9 \mathrm{a}$ & $14.37 \mathrm{a}$ & $85.30 \mathrm{a}$ & $10.49 \mathrm{c}$ \\
Moringa Extract & $16.65 \mathrm{a}$ & $5.7 \mathrm{~b}$ & $14.29 \mathrm{a}$ & $85.22 \mathrm{a}$ & $14.54 \mathrm{a}$ \\
\hline DMS & 0.06 & 0.08 & 0.95 & 3.49 & 1.80 \\
CV & 0.18 & 0.66 & 2.88 & 4.03 \\
\hline
\end{tabular}

The averages followed by the same letter do not differ statistically from each other (Tukey test $5 \%$ ). The letters compare averages in the column. ${ }^{* *}$ significant at the $1 \%$ probability level $(\mathrm{p}<0.1) *$ significant at the $5 \%$ probability level $(0.1=<\mathrm{p}<0.5)$. DMS Significant Deviation. CV - Coefficient of Variation.

For the Brix of the clarified juice (Table II), significant differences between treatments were observed, although the values were very close, the lowest value was for the control treatment. It should be noted that the values detected are lower than the extracted juice because prior to the juice clarification process, standardization was done for $16^{\circ}$ Brix for all treatments, but it can be concluded that the use of a treatment in juice, independent of the used flocculant, conserves more sugars than its non-use.

There has also been standardized $\mathrm{pH}$ (Table II), adjusted to 6.0, with the purpose of conserving nutrients which will be available in the fermentation process for yeasts. The values in this parameter had a significant difference, where the lowest value treatment was the moringa extract, reducing only $5 \%$, but this fact is already expected since there were reactions of ions drag between the calcium molecules and the phosphate of the juice.
This reduction can be considered insignificant by keeping nutrients available.

For Pol and Purity (Table II) no significant difference was observed, all were above the values expected by the industry, except for the purity of the control that was $2.83 \%$ below the recommended value (Amorim 2006).

In the technological parameter TRS (Table II), it was observed that there were considerable reductions when the dosages of 10 and $20 \mathrm{mg} . \mathrm{L}^{-1}$ were used, being $30 \%$ and $27.85 \%$ respectively, this drop can cause lower fermentation yields, when uses the polymers, these accelerate the process of drag of impurities, however, the high amount of this flocculant may have caused the drag of sugars as well.

Evaluating the acidity levels (Table III), it was observed reduction in all treatments, such removal is a result of treatment juice by liming, which adsorbs acid molecules and drag to the bottom of 
the decanter along with the calcium phosphates formed through the reactions between the added lime milk and the phosphates present in the raw material (Albuquerque 2011).

The ash contents (Table III) showed reductions in all treatments, and the control removed low contents of the order of $3.65 \%$ in relation to the extracted juice, followed by the seed extract with $13.41 \%$, the polymer with dosage of $1.5 \mathrm{ml} . \mathrm{L}^{-1}$, with $24.31 \%$ and the other three treatments the reduction was approximately $32 \%$, these values are close to another author when evaluated ash reduction with treatment of polymer, with reductions of $37 \%$. Another studies verified that the presence of ash did not reduce the efficiency of the fermentation process (Huang et al. 2017, Martins et al. 2016).

Comparing the effects of flocculants on turbidity (Table III), it was found that the use of the polymer with higher dosage resulted in a juice more translucent than the other treatments, achieving a removal rate of $62 \%$. The moringa extract removed approximately $43 \%$, being close to the other dosages. Turbidity removal is one of the main parameters for the clarification ability, as the higher turbidity is due to the presence of non-sugars in the juice, and the reduction of these sugars may indicate the removal of these components (gums, starch, protein) (Eggleston 2000, Freita et al. 2014). As for the phenolic compounds of the clarified juice (Table III), there were significant differences between the Control and the other treatments, where for this one, there was a smaller reduction being $15 \%$ and for the others approximately $35 \%$. Other authors obtained results similar to those observed in this research, noting the removal of phenols by the simple chalking process with the addition of flocculants. Some authors mention that this physico-chemical process is unable to reduce the content of these molecules in the juice and others believe that such removal of total phenolic compounds is directly related to the raw material processed, which varies not only the content of these compounds but also the characteristics of each one (Ravaneli et al. 2011, Costa et al. 2014b).

\section{CHARACTERISTICS AND FERMENTATION OF MUST}

Table IV established the mean values obtained for Total Acidity and Total Reducing Sugars (TRS) of the must prepared from clarified juice with the use of different flocculants.

TABLE III

Mean values obtained for Acidity, Ash, Turbidity and Phenol of the juice clarified with 5 sedimentation aids. JaboticabalSP. 2015/2016 crop year.

\begin{tabular}{|c|c|c|c|c|}
\hline Treatments & Acidity & Ash & Turbidity & Phenol \\
\hline Flocculant (F) & $\mathrm{g} / \mathrm{L} \mathrm{H}_{2} \mathrm{SO}_{4}$ & $\%$ & NTU & $\mathrm{mg} / \mathrm{L}$ \\
\hline Control & $0.64 b c$ & $0.79 \mathrm{a}$ & $876 a$ & $345 \mathrm{a}$ \\
\hline Polimer 1.5 & $0.84 \mathrm{a}$ & $0.62 \mathrm{c}$ & $775 \mathrm{a}$ & $287 b$ \\
\hline Polimer 5.0 & $0.75 \mathrm{ab}$ & $0.58 \mathrm{~cd}$ & $823 a$ & $259 b$ \\
\hline Polimer 10 & $0.60 \mathrm{c}$ & $0.57 \mathrm{~cd}$ & $763 a$ & $261 b$ \\
\hline Polimer 20 & $0.65 b c$ & $0.52 \mathrm{~d}$ & $413 b$ & $259 b$ \\
\hline Moringa Extract & $0.81 \mathrm{a}$ & $0.71 b$ & $615 \mathrm{ab}$ & $295 b$ \\
\hline DMS & 0.14 & 0.06 & 266.31 & 49.02 \\
\hline $\mathrm{CV}$ & 8.75 & 4.23 & 16.31 & 7.50 \\
\hline F & $10.23 * *$ & $56.23 * *$ & $8.57 * *$ & $9.84 * *$ \\
\hline
\end{tabular}

The averages followed by the same letter do not differ statistically from each other (Tukey test $5 \%$ ). The letters compare averages in the column. $* *$ significant at the $1 \%$ probability level $(\mathrm{p}<0.1) *$ significant at the $5 \%$ probability level $(0.1=<\mathrm{p}<0.5)$. DMS Significant Deviation. CV - Coefficient of Variation. 
Brix and $\mathrm{pH}$ were adjusted to $16 \pm 1$ and 4.5 \pm 0.3 respectively, the reason for which there was no significant difference between these parameters and is not in the and are not presented in any table.

Analyzing the Total Acidity of the must, it was observed that there was no significant difference for the treatments, which all presented an increase, precisely due to the correction of the $\mathrm{pH}$, which is made through the addition of acid.

For the TRS, it was observed that the treatments had a slight reduction in relation to the clarified juice, emphasizing that the treatments with 10 and $20 \mathrm{mg} . \mathrm{L}^{-1}$ are what are with low sugar contents.

The initial viability represents the amount of live yeast cells (\%), with Budding Index and Feasibility of the sprouts and adapted to compose the inoculum, yeast or foot of vat, destined to the accomplishment of the fermentative process. The results obtained are shown in Table V.

Considering that for ferments with high yields, the yeast must have cell viability greater than $85 \%$, it was observed that the yeast used in this test met

TABLE IV

Results for TRS and Total Acidity of the must obtained from clarified juice with 5 sedimentation aids. Jaboticabal-SP. 2015/2016 crop year.

\begin{tabular}{ccc}
\hline Treatments & Acidity & TRS \\
\hline Flocculant $(\mathbf{F})$ & $\mathbf{g} / \mathbf{L ~ H}_{\mathbf{2}} \mathbf{S O}_{\mathbf{4}}$ & $\mathbf{\%}$ \\
\hline Control & $1.07 \mathrm{a}$ & $13.12 \mathrm{bc}$ \\
Polimer 1.5 & $1.09 \mathrm{a}$ & $13.68 \mathrm{ab}$ \\
Polimer 5.0 & $1.06 \mathrm{a}$ & $12.40 \mathrm{c}$ \\
Polimer 10 & $1.04 \mathrm{a}$ & $9.96 \mathrm{~d}$ \\
Polimer 20 & $1.04 \mathrm{a}$ & $10.35 \mathrm{~d}$ \\
Moringa Extract & $1.05 \mathrm{a}$ & $14.45 \mathrm{a}$ \\
\hline DMS & 0.22 & 0.99 \\
CV & 23.22 & 3.52 \\
F & $0.25 \mathrm{~ns}$ & $69.78^{* *}$ \\
\hline
\end{tabular}

The averages followed by the same letter do not differ statistically from each other (Tukey test 5\%). The letters compare averages in the column. $* *$ significant at the $1 \%$ probability level $(\mathrm{p}<0.1) *$ significant at the $5 \%$ probability level $(0.1=<p<0.5)$. DMS - Significant Deviation. CV Coefficient of Variation. the recommendations stipulated by the sector, being $98 \%$ viable.

At the beginning of the fermentation process the lowest index was for the control treatment without addition of flocculants. The treatments with $10 \mathrm{mg} . \mathrm{L}^{-1}, 20 \mathrm{mg} . \mathrm{L}^{-1}$ and moringa extract were the highest rates of initial viability. In this sense it was verified that all the treatments were in the recommended percentage.

Evaluating the Budding Index and Feasibility of the sprouts, It was observed that sprouting did not differ as the viability of shoots differed for the control treatment with a viability $10 \%$ lower than the others. It is important for the industrial process that is feasibility of the largest possible, which can be reused for many cycles of fermentation. At the end of the fermentation, the percentage of live cells, bud index and shoot viability were again quantified, to better evaluate the impacts of the must submitted to different flocculants and the fermentation on the yeast. These results are presented in Table V.

The results obtained for the viability of cells and shoots at the end of the fermentation process did not present a significant difference; for the final viability of the cells, the control group presented a $14.74 \%$ reduction to the other treatments, and it is a highlight for the treatment with moringa extract where the viability of shoots was superior to all other treatments.

When comparing the beginning of shoot viability with the end of the process, it was noticed that this parameter increased, this fact is due to the decrease in the amount of sugars present in the substrate as the yeast consumes it to perform its metabolic processes.

When this concentration reaches values lower than $6 \%$, the yeasts metabolize sugars through their respiratory tract, which results in the production of ATP, glucose breakage in addition to new yeast cells (Venturini Filho et al. 2013). 
TABLE V

Results obtained for Cell Viability, Budding and Feasibility of Sprouts at the beginning and at the end of the fermentative process of musts obtained from clarified juice with 5 sedimentation aids. Jaboticabal-SP. 2015/2016 crop year.

\begin{tabular}{|c|c|c|c|c|c|c|}
\hline $\begin{array}{c}\text { Treatments } \\
\text { Flocculant (F) }\end{array}$ & $\begin{array}{c}\text { Cell } \\
\text { Viability } \\
\text { Beginning }\end{array}$ & $\begin{array}{c}\text { Cell } \\
\text { Viability } \\
\text { The end } \\
\end{array}$ & Beginning & The end & $\begin{array}{l}\text { Feasibility } \\
\text { of Sprouts } \\
\text { Beginning }\end{array}$ & $\begin{array}{c}\text { Feasibility } \\
\text { of Sprouts } \\
\text { The end }\end{array}$ \\
\hline \multicolumn{7}{|c|}{$\%$} \\
\hline Control & $87.33 d$ & $84.82 c$ & $12.37 d$ & $25.45 \mathrm{a}$ & $90.19 b$ & $84.83 b$ \\
\hline Polimer 1.5 & $95.92 b$ & $95.04 \mathrm{ab}$ & $21.80 \mathrm{a}$ & $25.74 a$ & $100 \mathrm{a}$ & $96.77 \mathrm{a}$ \\
\hline Polimer 5.0 & $92.73 \mathrm{c}$ & $92.14 b$ & $18.30 \mathrm{c}$ & $20.28 \mathrm{a}$ & $97.06 \mathrm{a}$ & $97.04 \mathrm{a}$ \\
\hline Polimer 10 & $98.37 \mathrm{a}$ & $94.34 b$ & $23.83 a$ & $24.57 \mathrm{a}$ & $97.31 \mathrm{a}$ & $96.33 \mathrm{a}$ \\
\hline Polimer 20 & $98.16 \mathrm{a}$ & $95.45 \mathrm{ab}$ & $21.08 \mathrm{a}$ & $25.23 \mathrm{a}$ & $98.84 \mathrm{a}$ & $97.83 \mathrm{a}$ \\
\hline Moringa E. & $97.94 a$ & $96.06 \mathrm{a}$ & $20.65 a$ & $23.48 \mathrm{a}$ & $100 \mathrm{a}$ & $99.50 \mathrm{a}$ \\
\hline DMS & 1.44 & 3.33 & 0.06 & 11.81 & 6.08 & 4.31 \\
\hline $\mathrm{CV}$ & 0.66 & 1.56 & 4.23 & 21.34 & 2.73 & 1.96 \\
\hline $\mathrm{F}$ & $192.19 * *$ & $39.52 * *$ & $56.23 * *$ & $0.63 \mathrm{~ns}$ & $7.66^{* *}$ & $36.39 * *$ \\
\hline
\end{tabular}

The averages followed by the same letter do not differ statistically from each other (Tukey test $5 \%$ ). The letters compare averages in the column. ${ }^{*}$ significant at the $1 \%$ probability level $(\mathrm{p}<0.1) *$ significant at the $5 \%$ probability level $(0.1=<\mathrm{p}<0.5)$. DMS Significant Deviation. CV - Coefficient of Variation.

\section{CHARACTERIZATION OF WINE}

Table VI shows the values obtained for $\mathrm{pH}$, Total Acidity, TRRS and Glycerol of the wine resulting from the fermentation process.

The brix of all treatments were $\leq 1.0$, evidencing that the fermentation had already been consumed. For the $\mathrm{pH}$ of the wines, it was observed that the sedimentation aids had a reduction. However, the lowest $\mathrm{pH}$ reduction was for the 20 $\mathrm{mg} . \mathrm{L}^{-1}$ polymer, however this is not an interferer of the process.

Evaluating the Total Reducing Residual Sugars (TRRS), it was observed that the control treatment had the highest percentage of the order of $0.1 \%$, while the others had close values, in this parameter values lower than $0.2 \%$ were expected, which all treatments were below this value.

For the acidity the contents varied from 2.33 to $2.62 \mathrm{mg} . \mathrm{L}^{-1}$, these results are close to those determined in another study that evaluated the Total Acidity of 12 fermentative cycles in an industrial unit, verified maximum levels of 2.2 mg.L.-1 (Mutton et al. 2012).
Glycerol is typically produced by yeasts with an inverse correlation with fermentative efficiency (Maiorella et al. 1983). In the present study the highest value was for the control, as expected, as soon as the juice had no treatment, with interferences in which it changes the metabolic route of the yeasts.

This fact is clearly observed in the alcoholic content and fermentative efficiency which, for the control, the alcohol content was 33\% lower than the $1.5 \mathrm{mg} . \mathrm{L}^{-1}$ polymer treatment, it is must mentioning that this content is the one used in Brazil by all the producing units and in spite of the treatment with moringa extract obtained values significantly close to this flocculant, similar fact occurred for fermentative efficiency. However, we must mention another study that evaluated the sedimentation velocity of the moringa extract in the same concentration used in this study, and obtained $0.3 \mathrm{~cm} \cdot \mathrm{min}^{-1}$ and also 0.5 of coagulant activity, values lower than the polymer (Costa et al. 2016).

The treatments with higher polymer contents remained statistically close, but below $80 \%$, 
TABLE VI

Results for pH, Total Acidity, TRRS, Glycerol, Alcohol Content and Fermentation Efficiency of the wine resulting from the fermentation process using the most prepared from clarified juice with 5 sedimentation aids.

\begin{tabular}{|c|c|c|c|c|c|c|}
\hline Treatments & pH & $\begin{array}{c}\text { Total } \\
\text { Acidity }\end{array}$ & TRRS & Glycerol & $\begin{array}{l}\text { Alcohol } \\
\text { Content }\end{array}$ & $\begin{array}{c}\text { Fermentation } \\
\text { Efficiency }\end{array}$ \\
\hline Flocculant (F) & & $\mathrm{g} / \mathrm{L} \mathrm{H}_{2} \mathrm{SO}_{4}$ & $(\%)$ & $(\%)$ & $(\%)$ & $(\%)$ \\
\hline Control & $3.37 b$ & $2.62 \mathrm{a}$ & $0.10 \mathrm{a}$ & $0.13^{\mathrm{a}}$ & $4.96 \mathrm{c}$ & $57.70 \mathrm{~d}$ \\
\hline Polimer 1.5 & $3.37 \mathrm{~b}$ & $2.25 \mathrm{e}$ & $0.07 b$ & $0.09 b$ & $7.00 \mathrm{a}$ & $87.02 \mathrm{a}$ \\
\hline Polimer 5.0 & $3.57 \mathrm{a}$ & $2.26 \mathrm{de}$ & $0.06 \mathrm{bc}$ & $0.08 \mathrm{~b}$ & $6.21 \mathrm{ab}$ & $78.01 \mathrm{bc}$ \\
\hline Polimer 10 & $3.45 b$ & $2.33 \mathrm{~cd}$ & $0.05 \mathrm{c}$ & $0.08 b$ & $5.66 \mathrm{bc}$ & $77.40 \mathrm{c}$ \\
\hline Polimer 20 & $3.69 \mathrm{a}$ & $2.45 b$ & $0.05 \mathrm{c}$ & $0.10 \mathrm{~b}$ & $5.63 \mathrm{bc}$ & $77.05 \mathrm{c}$ \\
\hline Moringa Extract & $3.35 b$ & $2.35 \mathrm{c}$ & $0.07 b$ & $0.08 b$ & $6.83 \mathrm{a}$ & $83.57 \mathrm{ab}$ \\
\hline DMS & 0.11 & 0.07 & 0.01 & 0.02 & 0.87 & 5.61 \\
\hline $\mathrm{CV}$ & 1.46 & 1.44 & 11.49 & 13.27 & 6.27 & 3.18 \\
\hline $\mathrm{F}$ & $18.75 * *$ & $67.01 * *$ & 23.85 & $7.65 * *$ & $16.91 * *$ & $69.15^{* *}$ \\
\hline
\end{tabular}

The averages followed by the same letter do not differ statistically from each other (Tukey test 5\%). The letters compare averages in the column. ${ }^{* *}$ significant at the $1 \%$ probability level $(\mathrm{p}<0.1) *$ significant at the $5 \%$ probability level $(0.1=<\mathrm{p}<0.5)$. DMS Significant Deviation. CV - Coefficient of Variation.

demonstrating that higher levels of flocculants did not improve the fermentation process.

\section{CONCLUSIONS}

In the treatment of the juice, the excessive addition of flocculants can lead to a decrease in sugars.

The moringa bioflocculant was similar in the technological characteristics and also in the fermentative viability compared to the usual commercial polymer dose in Brazil.

The alcohol content was greater for the treatment of flocculant polymer $1.5 \mathrm{mg} . \mathrm{L}^{-1}$, but bioflocculant moringa had similar values.

The fermentative efficiency was also higher for this flocculant, followed by the moringa extract.

The results obtained in this research indicate potential to bioextract moringa, especially in countries where the doses of flocculants are greater than $5 \mathrm{mg} \cdot \mathrm{L}^{-1}$.

\section{ACKNOWLEDGMENTS}

The authors would like to thank the Coordenação de Aperfeiçoamento de Pessoal de Nível Superior (Capes) for the scholarship granted.

\section{REFERENCES}

ABBI-ASSOCIAÇÃOBRASILEIRADEBIOTECNOLOGIA INDUSTRIAL. 2016. <http://agência.fapesp.br/brasil>. Acesso em 25 de Setembro de 2016.

ALBUQUERQUE LM. 2011. Processo de Fabricação de Açúcar. UFPE. $2^{\mathrm{a}}$ ed., Recife.

AMORIM H. 2006. Fermentação alcoólica, ciência \& tecnologia. Fermentec: Piracicaba.

AWAD M, WANG H AND LI F. 2013. Preliminary study on combined use of Moringa seeds extract and PAC for water treatment. Res J Recent Sci 2(8): 52-55.

COSTA GHG, FREITA CM, MENDES FQ AND MUTTON MJR. 2016. Extrato de sementes de moringa como floculante de caldo de cana-de-açúcar.

COSTA GHG, MASSON IS, FREITA LA, ROVIERO JP AND MUTTON MJR. 2014a. Use of Moringa oleifera Lamarck leaf extract as sugarcane juice clarifier: effects on clarifed juice and sugar. Food Sci Technol 34(1): 204-209.

COSTA GHG, MASSON IS, ROVIERO JP AND MUTTON MJR. 2014b. Reflexos do processamento de cana-deaçúcar bisada na qualidade do açúcar VHP. Boletim do Centro de Processamento de Alimentos 32(2): 281-288.

CTC. 2011. Manual de métodos de análises para açúcar. Piracicaba, Centro de Tecnologia Canavieira, Laboratório de análises, Disponível em CD ROM.

DELGADO AA AND CESAR MAA. 1977. Elementos de tecnologia e engenharia do açúcar de cana. v. 2. Zanini: Sertãozinho, $390 \mathrm{p}$.

EGBUIKWEM PN AND SANGODOYIN AY. 2013. Coagulation efficacy of Moringa oleifera seed extract 
compared to alum for removal of turbidity and E. coli in tree different water sources. European International Journal of Science and Technology 2(7): 13-20.

EGGLESTON G. 2000. Hot and cold lime clarification in raw sugar manufacture II: Lime addition and settling behavior. Int Sugar J 102(1221): 453-457.

FOLIN O AND CIOCALTEU V. 1927. On tyrosine and tryptophane determinations in proteins. J Biol Chem Bethesda 73(2): 627-650.

FREITA CM, COSTA GHG, MENDES FQ, MUTTON MJR AND FREITA LA. 2014. Moringa seed extract as sugarcane juice clarifier. Ciência Tecnol 6: 22-27.

GIROTTO F, ALIBARDI L AND COSSU R. 2015. Food waste generation and industrial uses: A review. Waste Manage 45: 32-41.

HUANG C, XINXING CLW, HUANG YJH, HUANG C, LI X AND YONG Q. 2017. An integrated process to produce bio-ethanol and xylooligosaccharides rich in xylobiose and xylotriose from high ash content waste wheat straw. Bioresource Technol 241: 228-235.

LEE SS, ROBINSON FM AND WONG HY. 1981. Rapid determination of yeast viability. Biotechnol Bioeng 11: 641-649.

MAIORELLA B, BLANCH HW AND WILKE CR. 1983. By-product inhibition effects on ethanolic fermentation by Saccharomyces cerevisiae. Biotechnol Bioeng 25: 103121.

MARTINS KC, FREITA CM, SILVA AF, ROVIERO JP, IRENE MC AND MUTTON MJR. 2016. Clarification of sugarcane juice with flocculants for sugar production. Ciência Tecnol 8: 149-153.

MENDES FQ, FREITA CM, COSTA GH, TEIXEIRA V, SILVA AS AND MUTTON MRJ. 2016. Microbiological behavior of yeast in must treated with different kinds of clarifying. Ciência Tecnol 8: 1-5.

MUTTON MJR, MISSIMA JOD, SILVANO N, SANTO RFP AND COSTA GHG. 2012. Qualidade tecnológica do melaço de cana-de-açúcar bisada. In: V Semana de Tecnologia do curso de Biocombustíveis - FATEC
Jaboticabal, Resumos da V semana de tecnologia, Jaboticabal, FATEC.

NOVOA JM, DUARTE-ALMEIDA AV, LINARES AF, LAJOLO FM AND GENOVESE MI. 2006. Antioxidant activity of phenolics compounds from sugar cane (Saccharum officinarum L.) juice. Plant Food Hum Nutr 61: 187-192.

OKUDA T, BAES AU, NISHIJIMA W AND OKADA M. 2001. Coagulation mechanism of salt solutionextracted active component in Moringa oleifera seeds. Water Res 35(3): 830-834.

RAVANELI GC, GARCIA DB, MADALENO LL, MUTTON MA, STUPIELLO JP AND MUTTON MJR. 2011. Spittlebug impacts on sugarcane quality and ethanol production. Pesqui Agropecu Bras 46: 120-129.

REIN P. 2012. Cane Sugar Engineering. $2^{\text {nd }}$ ed., Berlin: Bartens, $778 \mathrm{p}$.

RIPOLI TC AND RIPOLI ML. 2009. Biomassa de cana-deaçúcar: colheita, energia e ambiente. $2^{\mathrm{a}}$ ed., Piracicaba, $302 \mathrm{p}$.

ULLAH A, MARIUTTI R, MASOOD R, CARUSO IP, COSTA GH, FREITA CM AND MUTTON MJR. 2015. Crystal Structure of mature 2S albumin from Moringa oleifera seeds. Biochem Bioph Res Co 468(1-2): 365-371.

UNICA - UNIÃO CANAVIEIRA DO ESTADO DE SÃO PAULO. 2016. Perspectivas para os mercados de açúcar e etanol. <http://www.bmfbovespa.com.br/pt-br/download/ Marcos_Jank-Painel4.pdf>. Acesso em 02 de Outubro de 2016.

VENTURINI FILHO WG, BRUNELLI LT, TONIATO J, NOJIMOTO T AND NOVAES FV. 2013. Métodos simples para quantificar o metabolismo anaeróbio e aeróbio de leveduras alcoólicas. Boletim do Centro de Pesquisa e Processamento de Alimentos 31(2): 227-236.

YANG X, WANG K, WANG H, ZHANG J AND MAO Z. 2016. Ethanol fermentation characteristics of recycled water by Saccharomyces cerevisiae in an integrated ethanol-methane fermentation process. Bioresource Technol 220: 609-614. 